\title{
Industrial Conflict and the Local Community
}

\author{
By Edward T. Devine, Ph.D. \\ Author and Lecturer
}

$\mathrm{T}$ HE local community may come into contact with industrial conflict through (1) its courts; (2) its police department; (3) the Chamber of Commerce or civic or commercial clubs; (4) sympathetic trade unions or central trades councils or federations; (5) the churches; (6) special ad hoc committees, either self constituted or appointed by some other body, such as a mass meeting of citizens or the churches; (7) the newspapers; (8) the schools; (9) individual representative citizens; (10) intangible public opinion.

\section{The Courts}

The courts, deriving their powers from the sovereign state, exist to determine legal rights which may be in dispute between individuals, to ascertain whether alleged offenses against the laws have really been committed by the accused, and to assess damages and fix punishments. They also, in exercising these powers, have occasion to determine what the law really is: whether, for example, a statute is constitutional or an ordinance legal; whether a previous court order or injunction is valid; whether a policeman or other peace officer in a given instance has exceeded his powers; whether an indictment found by a grand jury shall be quashed for some reason or tried. From justice of the peace or police magistrate to the highest courts of appeal, the courts come into relation with industrial conflict, as with every other form of social conflict in which personal injury may occur and in which property rights are involved. In the most peaceful and orderly strike or lockout questions are likely to arise as to the enforcement or violation of existing agreements between employing corporation and wage-earners. In the greater and more prolonged conflicts there are likely to be riots, destruction of property, even loss of life, furnishing work for the criminal courts; and also delicate questions concerning the most fundamental of human rights, such as the right of assembly, the right of free speech, and the right of contract.

The impartiality and the competence of the judges who are to decide these questions are obviously the prime consideration. That there should be general confidence in the fairness of temper and also in the technical knowledge of the judges - in their knowledge not only of the principles of law and equity but also of those economic conditions out of which the disputes arise and the industrial relations in which the disputants stand to one another-. is greatly to be desired.

On the whole, employers and investors seem to have such confidence. The remark is not cynical. It is not that they have confidence because they think the judges will uniformly decide in their favor. This would be quite untrue. There are occasional decisions against the corporations. What the officers and directors of the employing corporations think, and those whose interests, large or small, are in profits and dividends, is that, on the whole, they get a fair hearing; that, when legislators become demagogues or local opinion prejudiced, the courts may be expected to give the protection to which even the unpopular are entitled; that the judges, especially the ap- 
pointed and long-term judges, are not likely to be influenced by the clamor of the multitude and the passions of the passing hour; that they sit more or less aloof from the influences which sway ordinary mortals, serene in their knowledge of the way in which similar issues have been settled in the past and determined to do justice though the heavens fall.

Unfortunately, this is not the way strikers or locked-out wage-earners ordinarily feel about the courts. It may be because of their ignorance or natural perversity, but the fact is certainly that they rather expect the courts to be antagonistic. They think they have had to wrest the right of peaceful picketing from reluctant judges; the right to collective bargaining in the face of ancient judge-made conspiracy laws. They think of injunctions in labor disputes as simply one more exceedingly effective weapon against them. They think that judges are human, like themselves, in that they are influenced by the current opinions, prejudices and passions of those with whom they associate, and that they do not, after their election to the bench, unless just before a re-election is in question, associate very much with wage-earners. They think that judges naturally and inevitably take the point of view of the prosperous, propertyowning classes rather than that of the industrial workers. They recognize that it is easier for a judge to be sympathetic with a particular individual criminal whom he may have to sentence -a murderer, forger, wife-beater-if there are exceptionally appealing circumstances, than to be sympathetic with a miscellaneous lot of milk-wagon drivers, for example, who by their strike appear to be the direct cause of much inconvenience or suffering in the community, or with railway employees or coal miners, when the supply of a necessary service or commodity is at stake.

It is a race between the better economic education of judges and of the legal profession from which they are necessarily drawn and the disaster which is surely involved in a complete and irrevocable loss of confidence in the courts on the part of the majority in industrial communities, or of so large a minority that, as in the case of several European nations, it may act like a majority. The present issue between the courts and the conservative American Federation of Labor in the use of injunctions is a straw which indicates currents of the wind. The storm has long been brewing. Such injunctions as have frequently and of late increasingly appeared in labor cases will be increasingly opposed and perhaps defied. New legislation, or wiser and more discriminating action by the courts, may prevent the growth of revolutionary hostility.

The remedy for the precarious state into which the courts have drifted is neither new nor startling. It is the remedy which Bar Associations and all thoughtful jurists advocate: the careful selection of candidates for judicial office from the highest to the lowest; selection based upon character, learning, a judicial temper, strict impartiality, keenness of understanding, a knowledge not only of the frame-work of the law but also of contemporaneous developments in industry and commerce, capacity for discarding traditional attitudes which no longer correspond to facts and courage in applying new knowledge - such qualities, for example, as have been most brilliantly illustrated by the two distinguished Bostonians who are now on the bench of the United States Supreme Court and as are equally well illustrated by the present deans of several law schools. It would be a very stimulating thing 
for the President to make the next appointments to the highest court and to other Federal courts from among these outstanding modern teachers of the law.

\section{Police Departments}

Police departments are seldom adequately equipped to deal with the disturbances incident to severe industrial conflicts. Their ordinary duties, miscellaneous and exacting as they are, do not especially prepare the ordinary policemen for handling riotous outbreaks, or for protecting either strikebreakers or pickets. The state militia has not in practice done very much better. The state constabularies or rangers have been more effective in some states, as far as the preservation of order is concerned, but they have not inspired confidence in their ability to confine their activities to this important service. The United States Army alone, in those unfortunate instances in which the disturbance has been grave enough to call for federal intervention, has been well enough officered and disciplined to know how to preserve order without becoming partisan. The experience of the officers in charge of the government troops in such instances has not been such as to make them especially keen about this kind of service.

The successful use of federal troops in this way, however, has not been without its effect on local police departments. They should be equipped and instructed for service in every emergency, and industrial conflicts are now likely to be among the most frequent of emergencies. They must learn the best means of controlling dangerous mobs, of preventing riots, of quelling them while they are incipient, of preventing lawless and illegal acts, while respecting both individual and collective rights. They must learn the difference between strikers and rioters, between pickets and vagrants, between incitement to riot and that chaffing which all disciplined soldiers and policemen take good-naturedly at its real value. But it is not only the individual policeman who requires instruction, training and discipline. Behind the policeman there must be a clarified and law-abiding public opinion. There must be a cheerful taxpayer, ready to furnish a police force large enough and sufficiently equipped. Much more important even than this is the need for a citizenry ready to back up the police in a reasonable display of force when this is necessary, in every courageous performance of duty.

The federal soldier may be individually far less capable than the individual policeman, but he has the prestige and the authority, with the government behind him, and his bearing is both more confident and more restrained. $\mathrm{He}$ is less nervous and less likely to be a bully. The local policeman is of course more likely to have personal friends among the strikers than a state constable or a federal soldier. He is more likely to be subjected to the annoyance of a personal complaint by some aggrieved citizen who may have influence with his superiors. He is even apt to have personal views on the merits of the controversy. There must be all the more determined effort to keep the policemen impartial, above personal partisanships or resentments, confident of recognition and support if he remains cool, good tempered and courageous. If his provocations are greater than those of a state constable or federal soldier, on the other hand, he will be on the ground earlier, he will know the local conditions better, and his interest in upholding the good name of the community for order and fair dealing is stronger. Those who have 
the opportunity to influence local public opinion in regard to industrial conflicts can do no better service than to put a discriminating and vigorous public sentiment behind those policemen who with tact, skill, good judgment and if necessary with self-sacrificing heroism, keep the peace while industrial conflict rages.

\section{Business Organizations}

The chambers of commerce, rotary clubs, and other associations made up mainly of business men, sometimes assume to be more representative of the community than they really are. They usually include clergymen, lawyers, editors and teachers. They often have some subordinate representatives of manufacturing or business houses as well as the heads. They seldom have serious representation of labor. They reflect the psychology of bankers, brokers, merchants or manufacturers. These are of course exceedingly important factors in the community, and they are entitled to their organs for creating, expressing, and propagating their own interpretation of current issues. It is greatly to be desired that organizations of this type should follow the example of the New Jersey State Chamber of Commerce in relying upon a qualified technical bureau for the study of subjects on which they are to express opinions. The more common practice is to appoint a committee which merely puts on paper opinions already current, snap-shot judgments, even on very complicated and controversial questions.

Frequently even this formality is omitted and a body which purports to represent the whole community will commit itself by resolution, with no further information than is attained by listening to an after-luncheon partisan address or to an obviously propagandist circular letter. Those who have a strong sense of community, whose sympathies are broad enough to embrace the interests of both wageearners and employers, women and men, farmers and dwellers in town, foreign-born and native, will not be too much impressed by the action of commercial organizations unless there is evidence that their action rests upon sympathies as broad as their own. Business men, however intelligent and broad-minded, cannot speak for workingmen as well as the latter, however inarticulate, can speak for themselves. Either the civic bodies so-called must be more inclusive in their membership, or their views must be taken for what they are: fragmentary, perhaps sound and perhaps unsound; one sided, perhaps right-sided and perhaps wrongsided, in any particular controversy.

\section{Labor Organizations}

The world of labor, like that of business, is accustomed to think of itself as self-sufficient. Their illusion is not often so complete. They are reminded often enough that there are other circles outside of and often hostile to their own. They are aware of these outside groups but not always fair to them. They resent sometimes-because coming from the outside - what are quite genuine efforts to promote causes in which they should be interested and in fact are interested when identified with labor. Labor looks to its own press, its own unions, its own leadershic for light on labor questions. In this, labor resembles business, and perhaps some other organized interests, say religion. But these closed charmed circles, whether religious or economic, are all equally inimical to normal human relations. Labor, like business, is entitled to its organs for creating, expressing and propagating its news. When trades councils speak they are speaking, and are fully conscious that 
they are speaking, for only one side. Nevertheless, they will get a hearing in proportion as they are able to identify their interests with those of the community as a whole, and in order to do this they have need of broad and verified knowledge, such as can come only from the coöperation of expert investigators, who may be at the same time absolutely loyal to the interests of labor, while also loyal to scientific method and the truth.

\section{The Churches}

The churches represent a different approach to industrial conflict. By hypothesis they are neither partisans nor, like the courts and police, indifferent as between parties. They are against conflict and for coöperation whenever conflicting interests can be reconciled or a basis found for coöperation. The finding of a basis and the reconciliation of conflicting interests may be their special task. They are for a way of life in which service rather than exploitation, good will rather than conflict, the truth which frees rather than the partial error which binds and blinds, are a matter of course. They are divided among themselves, but not on industrial questions. Against violence, injustice, oppression, hatred, every religion lifts its voice, every church protests. That they have a clear duty to assert their principles, their faith, in the midst of the local conflict is now scarcely denied. Just as the courts and the peace officers have to uphold law, so the churches have to uphold good will. They must insist on righteousness as firmly as the courts insist on law-abidingness, although the means by which they are respectively to be upheld are different. The courts pronounce verdicts enforced by sheriffs. The churches pronounce judgments enforced by moral influence. Alas for the churches which find their influence gone because they have not exercised it, because they have frittered it away on issues which are trivial.

The churches have their standards, by which the conduct of strikers and strike-breakers, employing corporations and their stockholders, courts and police, army or constabulary, may be judged. The community has a right to look to the churches to hold high these standards and in time of confusion and uncertainty to apply them in no uncertain terms. The churches, like chambers of commerce and tradeunions, have need of expert assistance in securing the information on which righteous judgments may be based. The inquiry into the facts made for the churches differs in no respect from the inquiry to be made for any other body which needs the same facts. There is no such thing as a religious investigation of industrial controversy; but there is such a thing as a religious reaction to the results of the investigation. There is a distinct part for the churches to play in the final determination of the relation between the community and industrial conflict.

\section{Citizen Committees}

Circumstances may be such as to justify and require the intervention of a special committee. The strikers may get out of hand and through a general strike imperil vital interests of society. The employers may seize virtual control of courts, constabulary, and organs of public opinion, and threaten even more obviously vital interests. There might be no indication of power of recovery on the part of the recognized social institutions. In self defense, the community may have to reorganize itself to afford the "first aid" required, as to an asphyxiated sufferer. More frequently, the committee may be needed merely to enable 
the people, harassed by conflicting evidence, to find out the truth. Such committees have now and then been of service as intermediaries at critical moments. Generally, however, an official mediator can better perform that service. The special committee is most useful in getting at the disputed facts, putting on record the results of its inquiries and interpreting its issues. Its members must expect to be criticized and even vilified. It is not a service for unduly sensitive souls. The outstanding instance of great service of this kind is not a purely local inquiry, but is one in which the interest was nation-wide, and the investigating body drawn also from the entire country-the Commission of Inquiry of the Interchurch World Movement, which investigated the steel strike of 1919 .

\section{The Press}

The newspapers are the natural and universal points of contact between the local community and the parties to an industrial conflict. What the general public knows about the issues involved, it gets chiefly through the daily pressand chiefly through the headlines at that. In advance of a strike the public mind is prepared by the editors and reporters. While it is in progress, a few will see for themselves, but even the incidents of the struggle are known to most as the press reports them. When a settlement is made its terms are understood as the press records and interprets them. After it is over the sediment of resentment or satisfaction, as the case may be, is such as the newspapers have discovered and preserve. This is not true of every section of the community. Employers have their secret service whose information may remain on file for future use. The workers have their personal and pooled experiences, the memory of which remains. The churches in rare instances may gradually accumulate the elements of a community conscience and memory. The courts add to their precedents. All these elements enter, in some degree; but as a rule, except in so far as they are reflected in newspaper stories, headlines and comments, they affect only a few individuals or groups. The labor world itself is not so organized that experiences of conflict, and the subsequent memory of them, become a common possession. The press is therefore the source, or at least the medium, from which the community learns about industrial conflicts, present, past and impending.

It is difficult to make any general statement about the press in its relation to industrial struggles to which exception could not be taken, supported by illustrations. That employers have more reason on the whole than wageearners to be satisfied with the newspapers could no doubt be proved. As in the case of the courts, they would probably attribute this not to any venality or partisanship of the owners or editors of the newspapers, but merely to what seems to them an obvious fact - that strikers and dissatisfied workers generally are almost certain to be in the wrong, to be ignorant and stupid people under the influence of radical agitators. Naturally, therefore, their acts cannot be presented otherwise than in an unfavorable, if not absurd, light, and naturally employers, coming from the better educated and intelligent classes of society, and knowing their business in its larger aspects, are more likely to be worthy of the favorable showing which they receive. What labor leaders have to say in an acute conflict is of course news, and as such will be reported. There are limits beyond which no self-respecting newspaper will go in suppressing or ignoring the grievances of workers, once they have been clearly formulated 
and established. Numerous instances could be cited of complete impartiality in presenting the two or more sides of particular controversies. The competition of the labor press, and the large circulation of certain newspapers, which are as capitalistic as any but cater to working people for sales, have created a certain security against the stifling of real news merely because it is favorable to labor's side of a controversy. This is not to say, however, that in particular communities the contrary may not be true. The papers which circulate in the tenements may be influenced by personal or political considerations, which in a given case may lead them to betray the very causes which they are supposed to represent. Personal idiosyncrasies of publisher or editor may suddenly distort the news as well as the editorial interpretation of it. In a particular city the whole level of the press, its standards of journalistic ethics, may be incredibly low. If so, the labor side of any serious conflict is apt to have a very raw deal. What is worse, the community is very likely to have misinformation and inadequate information.

The real grievance of the community with the press is less that there is bias than that there is lack of enterprise. The newspapers do not see the opportunities for legitimate journalistic effort which lie in exploring the dark continent of industrial anarchy. The wastes of industry which the engineering societies have been calling attention to have long been crying aloud to Heaven for exposure and correction. The public would be interested in knowing from the newspapers, if they would take the trouble to find out, what is really wrong with the building and textile industries, the railroads, the mining of coal. There is no reason why the press should wait for strikes and for Lockwood Committees. It is praiseworthy that they should report the strikes and the testimony extorted by Mr. Untermeyer, but the facts are there and would be news if brought out quite independently of such accidental or cataclysmic incidents. Crooked practices, whether involving so-called labor leaders or contractors or financial backers, can ordinarily be discovered more easily by newspapers than by grand juries or district attorneys. It should be regarded as a reflection on the press for the public to learn about them first from a legislative inquiry. If the Associated Press would send some of its best trained war correspondents into the coal, steel, railway, and textile territory, or even its cub reporters to the chambers of commerce to study the open shop movement, the community might get a service which is now lacking or very inadequately performed.

\section{The Schools}

That the schools should have any relation to industrial conflict may seem preposterous, and that they should be included among the points of contact may even arouse resentment. A veteran war correspondent has made an inquiry in Germany, France and England concerning the manner in which the causes, events and results of the World War are taught in the public schools of those countries. He finds that they are not taught at all. There is no agreement as to textbooks or as to what shall be taught; and therefore these children are growing up with little or no information about the history of the past ten years, no impressions about the most important events in all recorded history, except what they get from their parents, at any rate, no instruction from those who are charged with the special task of teaching them. This extraordinary gap in 
the preparation of European children is matched by an almost equally serious and perhaps equally unavoidable omission in our own schools. The World War presents little difficulty to our textbook writers and teachers; but the industrial conflict, the struggle for industrial democracy, we have not yet so much as begun to conceive as a suitable subject of instruction. We allow our children to get their preparation for industrial life from their parents and playmates, just as the Europeans are allowing theirs to get their only preparation for national and international citizenship from the same sources. There are many things which might be done to fill this gap. Social economics can be taught non-controversially as well as civics. There are many aspects of industrial organization which do not arouse antagonisms, and these at least could be taught. The field of industrial conflict could be narrowed by presenting those subjects to which exception is not likely to be taken. Not in the hour of conflict, but when it can be prevented by rational instruction in the principles of social economics, the schools may advantageously be brought more directly into relation with the general subject of industrial conflict, its causes, its manifestations, its remedies, its prevention.

\section{Private Citizens}

American experience richly illustrates the important rôle that individual citizens may play in preventing, mitigating, adjusting, or unfortunately in precipitating and aggravating, industrial conflict. Obviously, therefore, everything that can be done to increase the number of individuals in every occupation who have some understanding of underlying industrial facts, and of the facts which influence social behavior, will have its bearing in the moment of crisis. Again the inference is clear that disinterested expert inquiry and the dissemination of its results are the prime essentials.

\section{Public Opinion}

The community is more than its various elements separately analyzed. It is a living unit. Its public opinion is not the arithmetical sum of the contributions made by press, church, courts and other organs of public opinion. There is an intangible spiritual factor, a genius loci, struggling perhaps, as the ancients believed, against adverse or alien spirits for the wellbeing of the people. If the intangible public spirit of the community is really benignant, tolerant, socially generous, this will not be by accident. It will be the direct result of community thinking, community studies, mutual correction of various partial views, growth in the special virtues which distinguish a community from an unassimilated aggregation of human beings. If the community is to have a helpful relation to industrial conflict, it will be because its local government, courts, press, churches, civic bodies, trade unions, homes, and individual citizens are learning as they go along what conflict means, its origins and its costs, the means of control and prevention. Our facilities for getting such knowledge are meager. 